\title{
Study of Menarche Experience on Students of FKM UMJ
}

\author{
${ }^{1}$ Munaya Fauziah, ${ }^{2}$ Amira Mhuthia Adila, ${ }^{3}$ Bella Febriani, ${ }^{4}$ Deviana Aninda Putri, ${ }^{5}$ Dewi \\ Risqan Marfiah \\ Faculty of Public Health, Muhammadiyah University of Jakarta \\ K.H. Ahmad Dahlan St, Cireundeu, Ciputat, South Jakarta, 15419 \\ E-mail: amiraadila05@gmail.com
}

\begin{abstract}
According to the World Health Organization (WHO) about one-fifth of the world's population of adolescents aged 10-19 years. In Indonesia, 5.2\% of women experience menarche under the age of 12 from 17 provinces. The purpose of this study was to find out in-depth the experience of menarche in adolescent girls, especially in the Muhammadiyah University of Jakarta. The type of research used is qualitative research. The statements of the four informants regarding their knowledge of menarche were good, with various attitudes, behaviors, and responses. Reproductive health education is needed at this menarche phase. FKM UMJ students have various experiences regarding menarche or their first menstrual period.
\end{abstract}

Keywords: Menarche, Female students, Reproductive health 


\section{INTRODUCTION}

Adolescence is a period that experiences the most rapid physical development among the stages of human development. In addition to physical changes, adolescents also experience psychological changes. (1) According to Verawati and Liswidyawati (2012) stated that the puberty phase of a child who was originally asexual becomes sexual. This period is a period of psychological and social transition from childhood to adulthood that will end in the teens or early twenties. (2)

Menarche is the first menstruation that occurs in women, which is a characteristic of the maturity of a woman who is healthy and not pregnant (Yusuf, 2010). (3) Menarche occurs in early adolescence in the age range of 10-16 years. . Menarche is sometimes a big and scary problem for girls, making them shaken, embarrassed, and depressed, especially if they have never received the right information before (ed., 2005). (4)

Menarche can cause psychological changes for young women, including changes in psychological aspects that occur in young women, can be emotional, namely feelings of anxiety (Natsuaki, et al 2010). Adolescent knowledge about reproductive and sexual health in Indonesia based on a survey conducted by the BKKBN is relatively low seen from the lack of knowledge on reproductive health and gaps in fostering adolescent understanding of reproductive health (BKKBN, 2012). (5)

This phase of the arrival of menstruation is a period in which the girl is truly biologically ready to carry out her female functions. So for women, menstruation occupies a unique psychological existence, which can greatly influence a girl's perception of the reality of life, both during adolescence and after she becomes an adult. Psychological symptoms of menarche include anxiety and strong fear by the desire to reject the physiological process (Kartono, 2006). Adolescent girls who experience menarche often feel confused and sad (Dianawati, 2006). This happens because most teenagers do not understand the basis of the changes that occur in them. (6)

Adolescents in preparing for the arrival of menarche need support, both emotional support, information, appreciation, and instrumental. This support can be obtained from the family environment (parents), school environment (teachers), peer environment, and community environment (social culture and mass media). The environment in the family is the first and foremost environment for child development (Aryani, 2010). If a teenager is not given an understanding of menarche and is not prepared to face menarche there will be a feeling or desire to reject this physiological process, in adolescents sometimes there will be a wrong assumption about menstruation, they will think that menstruation is something dirty, impure, unclean and stained. Sometimes they will think they will die because a lot of blood comes out of the vagina (Mansur, Budiarti, 2014). (7) 
Demographic data show that the world's population of teenagers is large. According to the World Health Organization (WHO) about one-fifth of the world's population of adolescents aged 1019 years (Tarwoto, et al, 2010). About nine hundred million are in developing countries. Meanwhile, in Indonesia, from the results of the population census, of the total 237.6 million Indonesian population, 63.4 million of them are teenagers, $49.30 \%$ of the total youth are women (BKKBN, 2011). (8)

In Indonesia, women who experience menarche under the age of 12 years from 17 provinces are 5.2\%. The group of women in East Java who experienced menarche at the age of 6-8 years was $0.1 \%$, the age of $9-10$ years was $2.3 \%$, the age of $11-12$ was $25.3 \%$, the age of $13-14$ years was $36 \%$ and $17.2 \%$ aged $15-16$ years old, $3.5 \%$ aged $17-18$ years old, aged $19-20$ years old as much as $0.5 \%$ and 6.2\% of those who have not experienced menarche (Basic Health Research, 2010). (9)

Based on research conducted by Nurngaini (2003), emotional readiness in dealing with menstruation shows that: almost all of the subject's feelings are anxious, confused, tense, afraid, shocked, and excited. According to research conducted by Muryana (2008), the feelings of adolescents when experiencing menarche are fear, surprise, confusion and some even feel happy. Children's ignorance about menstruation can make it difficult for children to accept menarche (Aprilani, 2009). (10)

According to Conger (Sriwindari, 2002), of 475 young women, most of them feel normal, anxious, or afraid, and only $10 \%$ of them feel enthusiastic, curious, and proud when experiencing menarche. (6) Mental readiness is very necessary before menarche because feelings of anxiety and fear will arise, besides that there is also a lack of knowledge about self-care required during menstruation. The readiness of a young woman to face menarche is very important so that there is a need for clear information about the menstrual process and health during menstruation, especially from parents (Halimatussa'diah, 2008)

Parents play an important role in preparing their children to face puberty and need to convey information about sex and sexuality because parents are the first source where a child learns and is guided to know the sex (ed., 2004). Parents, especially mothers, have a great responsibility to teach about the changes at puberty that their daughters experience, including clear and correct information about menarche. (4)

Based on the background of the problem above, the researcher is interested in conducting an in-depth exploration of the experience of menarche in adolescent girls, especially in the area of the University of Muhammadiyah Jakarta. The benefit of this research is to provide information to young women at the University of Muhammadiyah Jakarta about menarche. In addition, this research provides benefits in the form of adding references in the field of health workers, especially Public 
Health, and as input for health workers in increasing the provision of information as early as possible to the public about menarche.

\section{METHODS}

The type of research used is qualitative research using participatory observational methods, where this research is carried out by interviewing respondents in-depth (in-depth interviews) which in general is a process of obtaining information for research purposes using question and answer while face to face or through communication media between interviewers and informants, with or without using interview guidelines. Interviews conducted by researchers lasted approximately 20-30 minutes.

\section{RESULTS AND DISCUSSION}

\section{Table 1. Interview Results}

\begin{tabular}{|c|c|c|c|c|c|}
\hline & QUESTIONS & Informant 1 & Informant 2 & Informant 3 & Informant 4 \\
\hline \multirow[t]{2}{*}{1.} & $\begin{array}{l}\text { What do you know about the } \\
\text { first menstruation of menarche? }\end{array}$ & $\begin{array}{l}\text { Puberty in young } \\
\text { women }\end{array}$ & $\begin{array}{l}\text { Menstruation in } \\
\text { adolescents }\end{array}$ & $\begin{array}{l}\text { Menstruation is an } \\
\text { event of bleeding } \\
\text { due to the shedding } \\
\text { of the uterine wall. } \\
\text { Bloody }\end{array}$ & $\begin{array}{l}\text { discharge from the } \\
\text { uterus of a woman's } \\
\text { vagina. }\end{array}$ \\
\hline & $\begin{array}{l}\text { a. Where did you get } \\
\text { information about it? }\end{array}$ & $\begin{array}{l}\text { General } \\
\text { knowledge } \\
\text { through the } \\
\text { internet }\end{array}$ & $\begin{array}{l}\text { Biology books for } \\
\text { sixth-grade } \\
\text { elementary school }\end{array}$ & $\begin{array}{l}\text { From lessons } \\
\text { finding out } \\
\text { yourself }\end{array}$ & $\begin{array}{l}\text { From your closest } \\
\text { family, especially }\end{array}$ \\
\hline \multirow[t]{6}{*}{2.} & $\begin{array}{l}\text { Tell me how was your } \\
\text { experience when you had your } \\
\text { first period? }\end{array}$ & $\begin{array}{l}\text { When you } \\
\text { experienced it for } \\
\text { the first time, you } \\
\text { were } \\
\text { surprised very } \\
\text { already and } \\
\text { understood the } \\
\text { cycle of puberty. }\end{array}$ & $\begin{array}{l}\text { When you took a } \\
\text { nap when you } \\
\text { graduated } \\
\text { elementary school, } \\
\text { you were }\end{array}$ & $\begin{array}{l}\text { surprised and } \\
\text { uncomfortable. }\end{array}$ & $\begin{array}{l}\text { A little worried } \\
\text { because women had } \\
\text { your first period }\end{array}$ \\
\hline & $\begin{array}{l}\text { a. when you had your } \\
\text { first period? }\end{array}$ & $\begin{array}{l}\text { When you are in } \\
\text { grade } 3 \text { junior } \\
\text { high school, }\end{array}$ & age 12, & $\begin{array}{l}\text { grade } 1, \text { junior high } \\
\text { school, when you } \\
\text { are }\end{array}$ & 12 years old, \\
\hline & $\begin{array}{l}\text { b. what are the signs and } \\
\text { symptoms that you } \\
\text { feel when you have } \\
\text { your first period? }\end{array}$ & $\begin{array}{l}\text { Symptoms you } \\
\text { feel you want to } \\
\text { eat continuously }\end{array}$ & No & $\begin{array}{l}\text { Stomach pain, } \\
\text { moodiness, fever, } \\
\text { acne, flatulence }\end{array}$ & $\begin{array}{l}\text { Abdomen The } \\
\text { uterus feels tight, }\end{array}$ \\
\hline & $\begin{array}{l}\text { c. what do you do when } \\
\text { you find out that you } \\
\text { are having your first } \\
\text { period? }\end{array}$ & Telling parents & $\begin{array}{l}\text { Use } \\
\text { napkins }\end{array}$ & Say, mother & $\begin{array}{l}\text { Clean your vagina } \\
\text { more often }\end{array}$ \\
\hline & $\begin{array}{l}\text { d. how do you prepare } \\
\text { for the first time you } \\
\text { have your period? }\end{array}$ & None & None & None & None \\
\hline & $\begin{array}{l}\text { e. } \text { during your first } \\
\text { menstruation, how was } \\
\text { your daily activity at } \\
\text { that time? }\end{array}$ & $\begin{array}{l}\text { Normal activities } \\
\text { Normal }\end{array}$ & activities & $\begin{array}{l}\text { Somewhat } \\
\text { uncomfortable with } \\
\text { activities }\end{array}$ & $\begin{array}{l}\text { Difficult to carry } \\
\text { out activities as } \\
\text { usual }\end{array}$ \\
\hline
\end{tabular}




\begin{tabular}{|c|c|c|c|c|c|}
\hline & QUESTIONS & Informant 1 & Informant 2 & Informant 3 & Informant 4 \\
\hline \multirow[t]{2}{*}{3.} & $\begin{array}{l}\text { Can you describe how you felt } \\
\text { when you had your first period? }\end{array}$ & $\begin{array}{l}\text { The feeling when } \\
\text { you experience it } \\
\text { for the first time is } \\
\text { shocked. }\end{array}$ & $\begin{array}{l}\text { Surprised when you } \\
\text { see menstrual } \\
\text { blood. }\end{array}$ & Surprised. & $\begin{array}{l}\text { Alhamdulillah, } \\
\text { puberty is fast, }\end{array}$ \\
\hline & $\begin{array}{l}\text { a. what is the meaning or } \\
\text { meaning of the first } \\
\text { menstruation for you? }\end{array}$ & $\begin{array}{l}\text { Menstruation is a } \\
\text { sign that someone } \\
\text { is an adult }\end{array}$ & $\begin{array}{l}\text { Menstruation is a } \\
\text { sign that someone } \\
\text { is an adult sign that }\end{array}$ & It's a & $\begin{array}{l}\text { we are going } \\
\text { through puberty }\end{array}$ \\
\hline \multirow[t]{2}{*}{4.} & $\begin{array}{l}\text { Are there any myths about } \\
\text { menstruation that you know? If } \\
\text { so can you tell me? }\end{array}$ & $\begin{array}{l}\text { Yes, shampooing } \\
\text { is not allowed, } \\
\text { drinking ice water, } \\
\text { not combing hair, } \\
\text { and drinking soft } \\
\text { drinks }\end{array}$ & $\begin{array}{l}\begin{array}{l}\text { Yes, drinking } \\
\text { ice } \\
\text { cubes }\end{array} \text { and } \\
\text { cucumber } \\
\text { freeze } \\
\text { blood }\end{array}$ & $\begin{array}{l}\text { It is forbidden to } \\
\text { cut nails, collect } \\
\text { haircare }\end{array}$ & $\begin{array}{l}\text { There are still many } \\
\text { myths about } \\
\text { menstruation, }\end{array}$ \\
\hline & $\begin{array}{l}\text { a. what do you think } \\
\text { about these myths? }\end{array}$ & $\begin{array}{l}\text { Looking for the } \\
\text { truth on the } \\
\text { internet }\end{array}$ & $\begin{array}{l}\text { believed it but not } \\
\text { after looking for } \\
\text { reliable information }\end{array}$ & $\begin{array}{l}\text { Confusion and tend } \\
\text { to look for the facts } \\
\text { first }\end{array}$ & $\begin{array}{l}\text { have to understand } \\
\text { more about } \\
\text { menstruation }\end{array}$ \\
\hline \multirow[t]{3}{*}{5.} & $\begin{array}{l}\text { After experiencing your first } \\
\text { period, did you feel any } \\
\text { changes? If so, can you tell us } \\
\text { about the changes you } \\
\text { experienced? }\end{array}$ & None & $\begin{array}{l}\text { Because you have } \\
\text { reached puberty, } \\
\text { you need to cover } \\
\text { your genitals when } \\
\text { you leave the } \\
\text { house. }\end{array}$ & $\begin{array}{l}\text { So you feel fertile, } \\
\text { spotty and your } \\
\text { breasts grow. }\end{array}$ & $\begin{array}{lr}\text { From } & \text { being } \\
\text { comfortable } & \text { to } \\
\text { uncomfortable, } & \end{array}$ \\
\hline & $\begin{array}{l}\text { a. how do you respond to } \\
\text { these changes? }\end{array}$ & None & $\begin{array}{l}\text { Mandatory to do it } \\
\text { because it is your } \\
\text { responsibility It's }\end{array}$ & little afraid It's & Okay be abnormal \\
\hline & $\begin{array}{l}\text { b. toin your opinion, do } \\
\text { you have any problems } \\
\text { during menarche or } \\
\text { first menstruation? If } \\
\text { there is, can you tell } \\
\text { me? }\end{array}$ & None None & No & $\begin{array}{lr}\text { Panic, yes, you } \\
\text { keep } & \text { getting } \\
\text { irregular } & \end{array}$ & No \\
\hline \multirow[t]{5}{*}{6.} & $\begin{array}{l}\text { How did your environment } \\
\text { respond after you found out that } \\
\text { you had your first period? }\end{array}$ & $\begin{array}{l}\text { The response of } \\
\text { the surrounding } \\
\text { environment is } \\
\text { normal }\end{array}$ & Surprised & $\begin{array}{l}\text { When you are } \\
\text { happy, it is a sign } \\
\text { that you are an } \\
\text { adult. }\end{array}$ & More advice \\
\hline & $\begin{array}{l}\text { a. Who was the first } \\
\text { person in your family } \\
\text { to know that you had } \\
\text { your first period? } \\
\text { Then, how did the } \\
\text { person respond at that } \\
\text { time? }\end{array}$ & $\begin{array}{l}\text { Mother, mother's } \\
\text { response was } \\
\text { normal. mother, }\end{array}$ & $\begin{array}{l}\text { Mother taught her } \\
\text { daughter what to } \\
\text { do. }\end{array}$ & $\begin{array}{l}\text { Mama was warier } \\
\text { and advised. }\end{array}$ & $\begin{array}{l}\text { Especially who was } \\
\text { warier of daughters. }\end{array}$ \\
\hline & $\begin{array}{l}\text { b. How did other families } \\
\text { react at that time? So } \\
\text { how do you respond to } \\
\text { this response? }\end{array}$ & No one responded & Surprised father & None & Normal \\
\hline & $\begin{array}{l}\text { c. How did your peers } \\
\text { respond when they } \\
\text { found out that you had } \\
\text { your first period? And } \\
\text { how do you react to } \\
\text { that? }\end{array}$ & Ordinary Ordinary & Ordinary & Ordinary & $\begin{array}{l}\text { Still curious about } \\
\text { menstruation, }\end{array}$ \\
\hline & $\begin{array}{l}\text { d. who do you trust to } \\
\text { discuss menstruation? }\end{array}$ & $\begin{array}{l}\text { No discussion } \\
\text { with anyone }\end{array}$ & $\begin{array}{l}\text { Islamic boarding } \\
\text { school friends who } \\
\text { understand fiqh }\end{array}$ & $\begin{array}{l}\text { Mamah and her } \\
\text { peers }\end{array}$ & $\begin{array}{l}\text { Mamah and close } \\
\text { friends }\end{array}$ \\
\hline
\end{tabular}




\begin{tabular}{|c|c|c|c|c|c|}
\hline & QUESTIONS & Informant 1 & Informant 2 & Informant 3 & Informant 4 \\
\hline \multirow[t]{3}{*}{7.} & $\begin{array}{l}\text { How do you take care of } \\
\text { yourself when you are } \\
\text { menstruating? }\end{array}$ & $\begin{array}{l}\text { Self-care is carried } \\
\text { out to keep around } \\
\text { reproduction and } \\
\text { change sanitary } \\
\text { napkins } \\
\text { frequently. }\end{array}$ & No special care. & $\begin{array}{l}\text { Change regular } \\
\text { sanitary napkins }\end{array}$ & \\
\hline & $\begin{array}{l}\text { a. how often do you } \\
\text { change sanitary } \\
\text { napkins during } \\
\text { menstruation? }\end{array}$ & $\begin{array}{l}\text { Every } 4 \text { hours } \\
\text { changing } \\
\text { napkins duritary } \\
\text { menstruation }\end{array}$ & $\begin{array}{l}\text { 3-4 times changing } \\
\text { every }\end{array}$ & $\begin{array}{l}4 \text { hours if normal. If } \\
\text { it leaks, replaces it } \\
\text { more often. The end } \\
\text { of menstruation can } \\
\text { take longer to } \\
\text { change change }\end{array}$ & .pads more \\
\hline & $\begin{array}{l}\text { b. often. How often do } \\
\text { you clean yourself } \\
\text { (shower) during } \\
\text { menstruation? }\end{array}$ & $\begin{array}{l}\text { Clean yourself } 2 \\
\text { times a day }\end{array}$ & 1-2 times & $\begin{array}{l}2 \text { times a day too } \\
\text { but if it leaks up to } \\
3 \text { times it }\end{array}$ & must be cleaner \\
\hline
\end{tabular}

Based on the statements of the four informants regarding their good knowledge of menarche, the four informants answered that menarche was an event of the first menstruation or an event of bleeding due to the rupture of the uterine wall. The four informants got this related information from the internet, lessons during elementary school, and their closest family.

The ages of the four informants experienced different menarche with an age range of 12-15 years. The symptoms felt by the informants varied from always feeling hungry, changes in mood, growing acne, even stomach pain, or feeling tied up. After knowing that the informant was menstruating for the first time, what he did was to inform his parents and always keep the reproductive organs clean. The four informants previously did not prepare for the first menstruation.

The feelings that the four informants felt when they found out that she had had her first menstruation were of course shocked, but one of the informants was also grateful for her fast puberty like her peers. Generally, menstruation does not interfere with the four informants in carrying out their activities. The meaning of the first menstruation for the informants is a sign that they have grown up.

The response of people around the informant when they found out that the informant was experiencing menstruation for the first time, among others, was more for support and advice. Informants also have a place for their discussion during menstruation like their peers, but some informants do not discuss this with anyone.

Regarding self-care during menstruation, the four informants did not take special care, except regularly changing their sanitary napkins to maintain cleanliness. The frequency of respondents changing sanitary napkins is in the range $>3$ times a day. While regarding bathing, respondents also showered 2 times a day to maintain personal hygiene during menstruation.

Adolescents have several different experiences during adolescence. They have different perceptions about premenstrual and postmenstrual behavior, which is by the results of previous studies, namely the first menstruation usually brings special and special memories for women. 
Different individual attitude changes during menstruation, such as anger, anxiety, and discomfort, depending on the understanding of knowledge and support of family members.

Menstruation is a problem that is often found with the highest prevalence in late adolescence. If left untreated, menstrual disorders can affect the quality of life and daily activities. Research on menstrual disorders in adolescents has not been widely carried out in Indonesia. (11)

The average age of menarche in elementary school students is at the age of 12 years with normal nutritional status, middle socioeconomic status, no exposure to mass media, and having a healthy lifestyle. The characteristics of respondents who differ on average are age, nutritional status, socioeconomic status, exposure to mass media, and lifestyle. Menstrual pain often occurs in young women, because they have not reached biological maturity (especially the maturity of the reproductive organs, namely the growth of the endometrium is still not perfect) and psychologically.

According to several previous studies stating that the lack of information related to reproductive and menstrual health education in adolescents, especially blind female adolescents will affect adolescent health and behavior patterns in menstrual personal hygiene, this is in line with several studies that participated stated the same thing that in Adolescents who lack knowledge and information about genital hygiene will also have an impact on adolescent behavior in maintaining the cleanliness of their genitals.

Due to certain cultural and religious boundaries, the role of mothers in imparting knowledge of menstruation is another important factor, especially since many young girls in rural Nigeria do not have sufficient information about menstrual hygiene. This can lead to improper and unhealthy practices during menstruation. Information about menarche is very important for adolescents, this is by the view of researchers who say that personal responses are very diverse, with positive or negative emotional reactions. Responses will vary depending on the understanding or level of knowledge and support of family members. (13)

Sometimes adolescents are not ready to face menarche due to lack of knowledge, so they have a desire to resist physiological processes, children will feel that menstruation is cruel and threatening, this situation can continue to develop in a more negative direction. strange fantasies The picture, coupled with meaningless anxiety and fear, can also be accompanied by feelings of guilt or guilt, all of which are related to problems with bleeding in the reproductive organs and menstruation. (14) For the first time the child communicates and interacts in the family environment, especially with the person closest to him, namely the mother. The bonding relationship between the child and the mother will continue until the child enters puberty.

Menstruation in the Qur'an is only mentioned four times in two verses. Once in the form of fil'mudlari (yahidi) and three times in the form of ism mashdar (al-maidi). In terms of naming alone, 
the word menstruation alone has been separated from the theological connotation like previous religions and beliefs. Lack of information about reproductive health results in many teenagers not having enough knowledge to deal with changes and problems during adolescence. Insufficient information on reproductive health causes adolescents to have misperceptions about reproductive health.

\section{CONCLUSION AND SUGGESTIONS}

FKM UMJ students have various experiences regarding menarche or their first menstrual period. This can be seen through their understanding, attitudes, and behavior, as well as support around menarche or their first menstrual event. Reproductive education is very necessary for the age leading to menstruation so that they are ready and able to face their menstrual period so that they can respond and behave by the recommendations in health.

Parents should provide a lot of education and support for their children who have started to experience their first menstruation. Education related to religion on how to respond to menstruation also needs to be instilled by both parents and the surrounding environment.

For teenagers who have entered their menstrual period, they should read more and explore things related to menstruation and try to avoid myths about menstruation if there is no scientific evidence.

For further researchers, they can conduct more in-depth research related to the attitudes and behavior of adolescents during menstruation so that they can be studied more deeply what these attitudes and behaviors are so that can be made policy brief in dealing with problems related to menstruation.

\section{REFERENCES}

1. Diaris NM. Ni Made Diaris Fakultas Ilmu Kesehatan Sains dan Teknologi Universitas Dhyana Pura , Bali , Korespondensi penulis : diaris.ade@gmail.com Abstrak PENDAHULUAN Masa remaja merupakan masa yang mengalami perkembangan fisik paling pesat diantara tahap-tahap per. 2018;11(2):87-92.

2. Muniroh M, Handayani S, Rina SW. Peran Ibu dalam Pemberian Informasi dengan Kesiapan Remaja Putri Menghadapi Menarche di SDN Palur 2 Mojobalan Sukoharjo. 2017;

3. Veronika A, Pengajar S, Santa S, Medan E. FAKTOR - FAKTOR YANG BERHUBUNGAN DENGAN PERILAKU REMAJA PUTERI DALAM MENGHADAPI MENARCHE DI SMP NEGERI 1 DELI TUA TAHUN 2015. 2015;1-14.

4. Rachmawati AN, Oktaviani AR. PERAN ORANGTUA DALAM MEMPERSIAPKAN KARANGANOM KABUPATEN KLATEN. 2017; 
5. Studi P, Sarjana K, Kesehatan FI, Aisyiyah U. Gambaran tingkat pengetahuan remaja putri dalam menghadapi menarche di sd negeri nogotirto yogyakarta. 2019;

6. Hidayah N, Palila S. Kesiapan Menghadapi Menarche pada Remaja Putri Prapubertas Ditinjau dari Kelekatan Aman Anak dan Ibu. 2021;5:107-14.

7. Saputro H, Ramadhani CM. Peran Orang Tua Dengan Sikap Remaja Putri Menghadapi Menarche. 2021;4(1):21-34.

8. Genetik P, Menarche U. Faktor-Faktor Yang Berhubungan Dengan Usia Menarche Pada Siswi Kelas VIII MTsN 1 Bukittinggi Tahun 2016. 2016;8(2):155-60.

9. Kesiapan G, Menarche M, Kalisat K, Jember K. Digital Digital Repository Repository Universitas Universitas Jember Jember Digital Digital Repository Repository Universitas Universitas Jember Jember. 2018;

10. Fakultas D, Kesehatan I, Muhammadyah U, Utara M. Dosen Fakultas Ilmu Kesehatan Universitas Muhammadyah Maluku Utara 1. 2019;1:1-11.

11. Muhammad Salim Alfaiz ESW. RESPON SISWI TERHADAP MENSTRUASI DALAM MELAKUKAN AKTIVITAS FISIK. :73-6.

12. Rustam E. Gambaran Pengetahuan Remaja Puteri Terhadap Nyeri Haid (Dismenore) dan Cara Penanggulangannya. J Kesehat Andalas. 2015;4(1):286-90.

13. Aras DU, Asbi NM, Ibrahim J. Gambaran Pengetahuan Tentang Kesehatan Reproduksi Pada Remaja Penyandang Disabilitas; Studi Kualitatif Pada Remaja Tunanetra Di Yayasan Pembinaan Tunanetra Indonesia (Yapti) Makassar. JIKI J Ilm Kesehat IQRA. 2019;7(Vol 7 No 01 (2019)):16-21.

14. Anwar C, Febrianty R. Hubungan Pengetahuan, Sikap dan Peran Ibu dengan Kesiapan Remaja Putri Menghadapi Menarche pada Siswi Kelas 4-6 di SD 3 Peuniti Kota Banda Aceh. J Healthc Technol Med. 2017;3(2):154. 